\title{
Electrolites and Heavy Metals in Coelomic Fluid of Sea Urchin, Arbacia lixula from Adriatic Sea: Biochemical Approach to Ecotoxicological Study
}

\section{Elektroliti i teški metali u celomskoj tekućini morskog ježinca Arbacia lixula iz Jadranskog mora: biokemijski pristup ekotoksikološkoj studiji}

\author{
Muhamed Fočak \\ University of Sarajevo \\ Faculty of Science \\ e-mail: mfocak10@gmail.com
}

\author{
Subha Džafić \\ University of Bihać \\ Biotechnical Faculty \\ e-mail: subha_buba@hotmail.com
}

\author{
Damir Suljević \\ University of Sarajevo \\ Faculty of Science \\ e-mail: suljevic.damir@gmail.com
}

Summary

The main circulatory medium of echinoderms is the coelomic fluid. Biochemistry of coelomic fluid is very complex and slightly different from seawater. The main aim of this research was to analyse concentration of electrolytes (potassium, calcium, magnesium, chlorine and sodium), heavy metals (lead, chromium, cadmium and cobalt) and iron in coelomic fluid of sea urchin, Arbacia lixula as an indirect indicator of seawater contamination. After precise statistical evaluation it was observed that electrolyte concentrations were; $\mathrm{Na} 189.20 \pm 11.41 \mathrm{mmol} / \mathrm{l}, \mathrm{Cl} 134.06 \pm 37.08 \mathrm{mmol} / \mathrm{l}, \mathrm{Mg} 4.24 \pm 1.08$ $\mathrm{mmol} / \mathrm{l}, \mathrm{Ca} 3.04 \pm 0.84 \mathrm{mmol} / \mathrm{l}$. Biochemical content of heavy metals in coelomic fluid was; Co $1.292 \pm 0.879$ ppm, Pb 0.644 \pm 0.131 ppm, Cr $0.116 \pm 0.055$ ppm, Cd $0.031 \pm 0.017$ ppm and iron $0.259 \pm 0.058 \mathrm{ppm}$, and it depends on the potential accumulation level in the organism. The composition of electrolyte and heavy metal content varies depending on the composition of seawater. Obtained values are within the range of values most commonly found in low polluted areas of the Adriatic sea. Similar models may be applied for monitoring of heavy metal contamination in marine environment.

\section{Sažetak}

Glavni cirkulatorni medij bodljokožaca je celomska tekućina. Celomska tekućina ima složen sastav i različita je od sastava morske vode. Glavni cilj ovog istraživanja bio je analiza koncentracije elektrolita (kalija, kalcija, magnezija, klorida i natrija), teških metala (olova, kroma, kadmija i kobalta) i željeza u celomskoj tekućini morskog ježinca Arbacia lixula, kao neizravnih indikatora onečišćenja morske vode. Nakon precizne statističke analize utvrđeno je da su koncentracije elektrolita iznosile ( $\mathrm{Na} 189.20 \pm 11.41 \mathrm{mmol} / \mathrm{l}, \mathrm{Cl} 134.06 \pm 37.08 \mathrm{mmol} / \mathrm{l}$, Mg 4.24 $\pm 1.08 \mathrm{mmol} / \mathrm{l}, \mathrm{Ca} 3.04 \pm 0.84 \mathrm{mmol} / \mathrm{l})$. Biokemijski sadržaj teških metala je iznosio (Co $1.292 \pm 0.879$ ppm, Pb 0.644 \pm 0.131 ppm, Cr 0.116 \pm 0.055 ppm, Cd $0.031 \pm 0.017$ ppm) i željeza $0.259 \pm 0.058 \mathrm{ppm}$, te je ovisio o stupnju akumulacije u organizmu. Sastav celomske tekućine u pogledu koncentracije elektrolita i teških metala varira ovisno o sastavu morske vode. Dobiveni rezultati su u razini vrijednosti koje se mogu naći u područjima s niskim stupnjem onečišćenja u Jadranskom moru. Slični modeli mogu se i ubuduće primijeniti u praćenju onečišćenja teških metala u morskom okolišu.

\section{INTRODUCTION / Uvod}

Coelomic fluid of echinoderms contains organic compounds, including amino acids, reduced sugars, proteins, lipids and nitrogenous waste. The coelomic fluid system consists of numerous rings and channels and has the function of transporting nutrients.

The body fluids in echinoderms are similar to the surrounding seawater with the exception of potassium, sulphate ions and organic content. Coelomic fluid has enhanced amino acid and $\mathrm{K}^{+}$concentrations, but reduced $\mathrm{Na}^{+}$and $\mathrm{Cl}^{-}$concentrations,

\author{
DOI 10.17818/NM/2019/2.1 \\ UDK 593.95:577.3 \\ $551.464(262.3)$ \\ Original scientific paper / Izvorni znanstveni rad \\ Paper accepted / Rukopis primljen: 15. 10. 2018.
}

\section{KEY WORDS \\ Adriatic sea \\ Arbacia lixula \\ ecotoxicology \\ electrolytes \\ heavy metal}


of sea urchins. Studies have found that A. lixula has lower concentrations of $\mathrm{Na}^{+}$and $\mathrm{K}^{+}$when compared to $L$. variegatus which makes it an isoconformer. In this research, seawater was either proportionally diluted with filtered dechlorinated tap water, or diluted and supplemented with magnesium as $\mathrm{MgCl}_{2}$ up to full-strength seawater $\mathrm{Mg}^{2+}$ levels, where $L$. variegatus displayed higher CF osmolality, $\mathrm{Na}^{+}$and $\mathrm{K}^{+}$values than the water and A. lixula [2]. Researches on Arbacia lixula did not show evidence for the maintenance of $\mathrm{Mg}^{2+}$ gradients [3].

Most types of pollution, regardless of its initial source, ultimately finds its way into the aquatic realm and heavy metals are no exception. Heavy metals from water may affect organisms by accumulating in their bodies or by transferring to the next trophic level of the food chain. Accumulated heavy metals in the tissues of aquatic animals and may become toxic when accumulation reaches high level. Accumulation of heavy metals in tissues mainly depends upon concentration of metals in water and exposure period; although some other environmental factors such as salinity, $\mathrm{pH}$, hardness and temperature play significant roles in metal accumulation. Comparisons of levels of heavy metal pollution in aquatic environments are undertaken by analysis of water, sediments and members of indigenous biota, i.e. bioindicators [4, 5]. Aquatic organisms exposed to a higher concentration of heavy metals in water may take up substantial quantities of these metals. The effects of toxic chemicals and complex mixtures in early developmental stages of marine organisms are of great importance in the protection of health in natural populations. Sea urchins are one of the most sensitive and suitable test organisms for testing acute biological pollution. Studies show that numerous chemical contaminants in the environment have toxic effect on the development of organisms [6]. Previous research linked the effects of environment upon chemical and cellular properties of coelomic fluid of sea urchins, such as study of Nekvapil et al., 2018 [7]. Their research is based on using carotenoids in coelomic fluid as possible indicator of environmental change in order to support the idea of using composition of coelomic fluid as an indicator of environmental pollution. It is therefore thought that coelomic fluid contains metabolised pollutants, so analysis of coelomic fluid is an important factor which correlates with the quality of the seawater. Paracentrotus lividus (stony sea urchin) is usually used for testing marine toxicology in Mediterranean se, while A. lixula shares areal with $P$. lividus in mediterranean region and in Atlantic ocean. They have different food substrate, where $P$. lividus forages on algae and seaweed and A. lixula on coralline algae (order: Corallinales) and sessile invertebrates [8].

Heavy metals released from natural and anthropogenic sources can reach the marine environment and be accumulated through food chain. Despite of their function in oxidationreduction reactions, excess amount can cause tissue and cell damage. The presence of heavy metals in water reduces its quality and increases their accumulation in organisms [9]. Chronic stress, such as repeated exposure to heavy metals, causes suppression of non-essential functions such as loss of neuronal function and a change in response to additional stressors [10].

Although exposure to heavy metals does not usually cause deadly consequences, sublethal effects have been reported including behavioural and physiological changes [11]. Different anomalies in sea urchin development are induced by polluted waters. Heavy metal analysis shows us that the organisms that live in contaminated area incorporate into their skeletons greater quantities of these elements than those that live in nonaffected areas [12]. Many researchers reported that anomalies could be induced after exposure to heavy metals. It may lead to correlation of the cause with some specific metal if it can be shown that certain metals cause specific anomalies with unique characteristics, such as an abnormal shape of the embryos $[13,14]$.

The main aim of this research was to analyse concentration of electrolyte (potassium, calcium, magnesium, chlorine and sodium) and to assess heavy metal (lead, chromium, cadmium and cobalt) and iron in coelomic fluid of $A$. lixula as indirect indicator of potential marine pollution.

\section{MATERIAL AND METHODS / Materijali i metodologija}

\section{1. Study area and sampling of coelomic fluid /} Područje proučavanja i uzorkovanje celomske tekućine Electrolytes and heavy metals concentrations, from the coelomic fluid of sea urchin, A. lixula, were analysed. Animal sampling $(n=30)$ was carried out in the region of Central Adriatic Sea $\left(43^{\circ} 27^{\prime}, 17^{\circ} 03^{\prime}\right.$, Hvar channel) during August, 2016. Coelomic fluid was collected by non-invasive method which included needle aspiration $(0.88 \mathrm{~mm})$ in the area of peristomal membrane at an angle of $45^{\circ}$ where, $0.5 \mathrm{ml}$ of coelomic fluid was collected. Animal protocols were conducted in accordance with Directive 2010/63/EU on the protection of animals used for scientific purposes. Animals were returned to their natural habitat after sampling. The collected samples were transferred to eppendorf tubes (1,5 ml; Eppendorf 3810X) and stored in a refrigerator $\left(+4^{\circ} \mathrm{C}\right)$.

\section{2. Electrolyte analysis / Analiza elektrolita}

All electrolytes concentrations were analysed by a spectrophotometric method (Spectronic GenesysTM 20). The O-cresolftalein method (SMG Italy) was used to analyse calcium and mercuro-thiocyanate method for chloride analysis (SMG Italy). The concentration of magnesium was analysed by the xyilid-blue method (Futura System, Italy), while sodium concentration was determined by deposition method with magnesium-uranyl acetate (Futura System, Italy).

\section{3. Analysis of heavy metals / Analiza teških metala}

Atomic absorption spectrophotometry (Analytical Methods, FP-3) was done using Perkin Elmer AAnalyst-800 for heavy metals (lead, iron, chromium, cadmium and cobalt) analysis. Preparation of samples implies combustion of coelomic fluids at $500{ }^{\circ} \mathrm{C}$ (Milestone, Start D) to produce ash where heavy metals were analysed.

\section{4. Statistical analysis / Statistička analiza}

All results were analysed in IBM SPSS Statistics 20 programme. The frequency and distribution normality were analysed by Shapiro-Wilk W test, parameters with high coefficient of variation. $p$-values below 0.05 were considered statistically significant. Results were presented as means, standard deviations, range and coefficient of variation. 


\section{RESULTS / Rezultati}

\section{1. Electrolites / Elektroliti}

After statistical analysis results are presented as it follows. Mean values with range variation of electrolytes in sea urchin coelomic fluid are presented in Fig. 1.

The lowest individual variations were observed for sodium concentrations, while coefficient variation of calcium and chloride were higher than expected. The values of electrolytes in coelomic fluid were: $\mathrm{Na}^{+}(189.20 \mathrm{mmol} / \mathrm{l}), \mathrm{Cl}^{-}(134.06 \mathrm{mmol} / \mathrm{l})$, $\mathrm{Mg}^{2+}(4.24 \mathrm{mmol} / \mathrm{l})$ and $\mathrm{Ca}^{2+}(3.04 \mathrm{mmol} / \mathrm{l})$. The greatest range among individual variations was observed in chloride concentration, with highest standard deviation in comparison to other electrolytes (Fig. 1.).
Table 1 presents correlation between analysed electrolytes. These values are shown as positive and negative correlation with significant values.

Positive correlation was observed between analysed electrolytes, except for chloride and sodium concentrations. Significant differences were obtained between calcium and magnesium concentrations, so as between calcium and chloride. High correlation were observed between concentrations of calcium and magnesium (0.945).

\section{2. Heavy metals / Teški metali}

Concentrations of heavy metals in celomic fluid of sea urchin, $A$. lixula are presented in Table 2. Concentratios are expressed as ppm (parts per million).

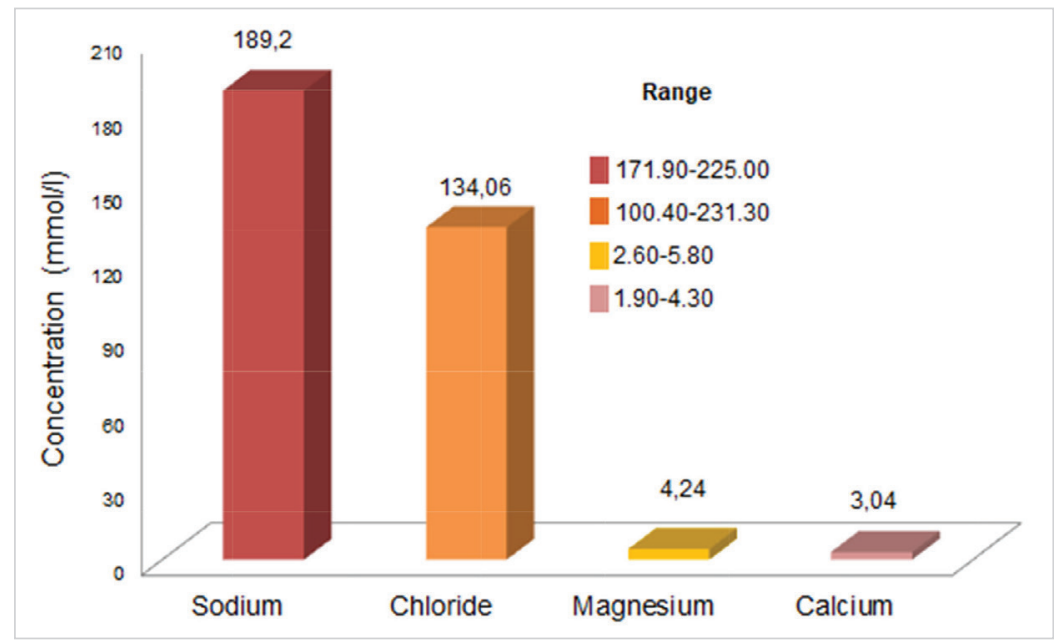

Figure 1. Values of electrolytes in A. lixula coelomic fluid Slika 1. Vrijednosti elektrolita u celomskoj tekućini A. lixula

Table 1 Spearmann's rho test of correlation between electrolytes concentrations Tabela 1. Spearmanov rho test korelacije između koncentracije elektrolita

\begin{tabular}{|l|c|c|c|c|c|c|c|c|}
\hline & \multicolumn{3}{|c|}{$\mathrm{Na}^{+}$} & \multicolumn{3}{c|}{$\mathrm{Ca}^{2+}$} & \multicolumn{3}{c|}{$\mathrm{Mg}^{2+}$} & \multicolumn{2}{c|}{$\mathrm{Cl}^{-}$} \\
\hline & $\mathrm{R}$ & Sig. & $\mathrm{R}$ & Sig. & $\mathrm{r}$ & Sig. & $\mathrm{r}$ & Sig. \\
\hline $\mathrm{Na}^{+}$ & - & - & 0.222 & 0.410 & 0.343 & 0.193 & -0.122 & 0.652 \\
\hline $\mathrm{Ca}^{2+}$ & 0.222 & 0.410 & - & - & 0.945 & $0.000^{* *}$ & 0.664 & $0.005^{* *}$ \\
\hline $\mathrm{Mg}^{2+}$ & 0.343 & 0.193 & 0.945 & $0.000^{* *}$ & - & - & 0.563 & $0.023^{*}$ \\
\hline $\mathrm{Cl}^{-}$ & -0.122 & 0.652 & 0.664 & $0.005^{* *}$ & 0.563 & $0.023^{*}$ & - \\
\hline
\end{tabular}

* Statistically significant at 0.05 level

** Statistically significant at 0.01 level

Table 2 Concentrations of heavy metals in A. lixula coelomic fluid Tabela 2. Koncentracije teških metala u celomskoj tekućini A. lixula

\begin{tabular}{|l|l|l|l|}
\hline \multicolumn{1}{|c|}{ Heavy metal $(\mathrm{ppm})$} & Mean \pm stdv & Range & KV (\%) \\
\hline Cobalt & $1.292 \pm 0.879$ & $0.292-2.808$ & 68.067 \\
\hline Chromium & $0.116 \pm 0.055$ & $0.044-0.176$ & 47.487 \\
\hline Lead & $0.644 \pm 0.131$ & $0.492-0.818$ & 20.407 \\
\hline Iron* & $0.259 \pm 0.058$ & $0.203-0.360$ & 22.286 \\
\hline Cadmium & $0.031 \pm 0.017$ & $0.012-0.063$ & 55.527 \\
\hline
\end{tabular}

* Iron could be included in complex biochemicals, not necessarily being classified as a heavy metal pollutant 

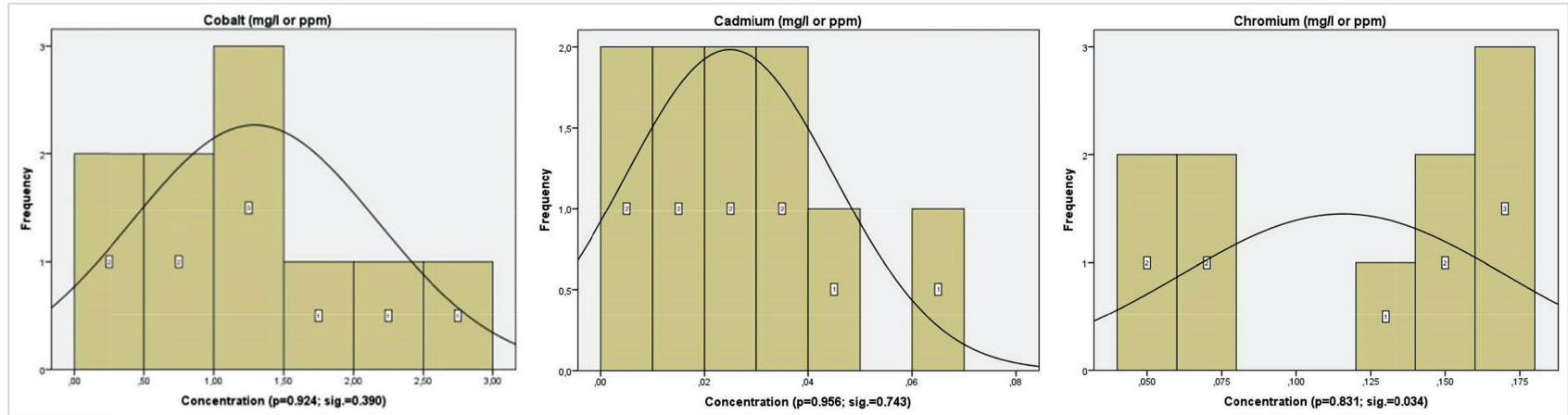

Figure 2. Frequency and normality for concentrations of cobalt, chromium and cadmium in coelomic fluid Slika 2. Frekvencija i normalitet distribucije koncentracija kobalta, kroma i kadmija u celomskoj tekućini

Values of heavy metals in coelomic fluid showed greater variations in comparison to electrolytes. Mean values of heavy metals were: $\mathrm{Co}$ (1.292 ppm), Pb (0.644 ppm), Fe (0.259 ppm), Cr (0.116 ppm) and $\mathrm{Cd}(0.031 \mathrm{ppm})$. Exceptionally high variations were observed for cobalt (68.067\%), cadmium (55.5275) and chromium (47.487\%).

Figure 2. shows results for frequencies and normality for cobalt, cadmium and chromium concentrations. Analysis was done for parameters which had shown highest coefficients of variations.

Shapiro Wilk W test showed that chromium concentrations had significant deviation from normal distribution $(p=0.034)$, while cadmium and cobalt concentrations had normal distribution ( 0.743 and 0.390 respectively), regardless of their high coefficients of variation (Fig. 2.).

\section{DISCUSSION / Rasprava}

\section{1. Electrolites / Elektroliti}

Biochemical analysis of coelomic fluid, especially electrolyte composition is important to understand biochemical and physiological processes in the adaptation of marine organisms. These adaptations are very different in relation to terrestrial organisms, and especially different when these mechanisms are compared with freshwater organisms. Researches on the composition of minerals in coelomic fluid of $A$. lixula are very poor. Certain differences are observed, especially for magnesium concentration in comparison to related species such as Echinometra lucunter and $L$. variegatus. Recent studies on related species show similar values of electrolytes, except for magnesium concentrations. The reason for this is the significant role of magnesium ions in metabolic processes, rather than osmoregulation. The phylogenetic closely-related species, $E$. lucunter has similar coelomic fluid content as reported for $A$. lixula [2]. A comparative study of on $L$. variegatus and $A$. lixula showed that $A$. lixula coelomic fluid contained less $\mathrm{Na}^{+}$and $\mathrm{K}^{+}$ ions compared to L.variegatus. Lower ion values suggest that this species belongs to iso-osmoconformers, which leads to the conclusion that this species is very sensitive to high osmotic variations of ions in seawater [3]. The sodium ions have an important role in the short-term regulation of salinity changes because they are first mobilized during the cell osmoregulation $[15,2]$. Therefore, sodium ions are essential for successful osmoregulation.

Calcium values are high due to the enzymatic and structural role in the composition of the skeleton (90\%) and are very similar to the values measured in study of Freire et al., 2011
[2]. The presence of calcium ions is very important for the activation of the SM30 and SM50 proteins involved in the mineralization process [16]. Researches showed that changes in magnesium, calcium or potassium concentrations affect the activity of metabolic processes and muscle activity [1721]. Brennand et al., 2010. [22] came to the conclusion that ocean warming and its acidification slow down the saturation of calcium carbonate, which is crucial for skeleton calcification. According to our results, the area of sampling was not subject of mentioned acidification, since significant deviations in the calcium concentration were not observed. According to Böttger et al., 2004 [15], concentrations of sodium and chloride ions are important for cell osmoregulation which was confirmed in our research. Since electrolyte content varies depending on the composition of seawater, it is not possible to establish uniform reference values for these biochemical parameters.

\section{2. Heavy metals / Teški metali}

Contamination in the aquatic ecosystem causes different harms in the organisms, at the level of population and environment, as in organ functions and biological biodiversity. Sea urchin is one of the most suitable model organisms for monitoring marine pollution $[23,24]$. The aquatic organisms are sensitive to heavy metals when the concentrations of the metals achieve significant level in the water and sediment [25].

Heavy metals are terrestrially produced by industrial and agricultural activities and they flow into the sea through effluents and sewage or are directly discharged on the sea waterfront. Heavy metal concentrations seem to be similar to the other low-impact areas in Adriatic Sea [26, 27]. This clearly indicates the influence of aquatic environments as well as surrounding human activities may contribute to accumulation of heavy metals. Accumulation of heavy metals in the aquatic environments have been associated with urban runoff, sewage treatment plants, industrial effluents and wastes, boating activities, domestic garbage dumps and agricultural fungicide runoff.Sea urchin embryos of Paracentrotus lividus were treated with lead and reduction of HSP70 synthesis was observed. In research of Bonsignorea et al., 2018 [28], signficantly higher concentrations of heavy metals $(\mathrm{Cr}, \mathrm{Pb}$ and $\mathrm{Cd})$ were observed in the Tuscany coast region.

In seawater, the metal is present primarily as the $\mathrm{Co}^{2+}$ ion. According to Nolan et al., 1992 [29] there is preferential uptake and retention of cobalamine-associated cobalt by marine biota. We observed high concentrations of cobalt in coelomic fluid. Natural release of cobalt into the aquatic environment could be 
due to the possible decomposition of plant waste, while human releases of cobalt are very limited and include production of alloys and chemicals and urban run-off $[30,31]$.

Our research showed that mean concentration of lead was 0.644 ppm. Lead accumulation is associated with a reduction of body calcium accumulation [32]. Metabolic rate of the organism, exposure route, mobility of metal, bioavailability and type of chelator present in water and time spent in the contaminated water are among the major factors for the variation in metal accumulation rate [33-36]. Sales of leaded gasoline in the Republic of Croatia ceased at the beginning of 2006, which significantly reduced the level of exposure of the general population. However, lead from industry and waste waters could be the reason for its accumulation in coelomic fluid. Mean concentration of cadmium was $0.031 \mathrm{ppm}$ and it has role in regulation of antioxidant enzymes expression, metallothioneins and heat shock proteins (HSPs) and downregulates the expression of digestive enzymes. It also interferes with tissue organization, immune responses by inducing apoptosis. Cadmium uptake from water by aquatic organisms is extremely variable and depends on the species and various environmental conditions. Sublethal effects have been reported on the growth and reproduction of aquatic invertebrates [37].

Our research showed that mean chromium concentration in coelomic fluid was $0.116 \mathrm{ppm}$. This metal is highly toxic trace metal, presenting various degrees of risk for coastal ecosystems. Recent researches on mussel, Mytilus galloprovincialis and crab, Petrolisthes laevigatus were used in a standard toxicity bioassay. The results demonstrate that chromium significantly affects functional and molecular parameters in mussel gills and crabs (Petrolisthes laevigatus) $[38,39]$. It was found that acute toxicity is extremely variable. Fish appeared to be considerably less sensitive than invertebrates [3]. Chromium accumulation in the sea is primary a result of compounds used in ferrochrome production, electroplating, pigment production, tanning and waste incineration. The chromium remains long in the form of fine floating particles in the atmosphere and is easily transferred over long distances [40]. In order to protect the health of consumers in the Republic of Croatia, the Law on contaminants (NN 39/13) provides the implementation of Commission Regulation (EC) No. 1881/2006 on the determination of the maximum permitted quantities of certain contaminants in food, including all amendments. The Regulation and its amendments determine the maximum allowed quantities of lead, cadmium and mercury in fish, crustaceans, shellfish and cephalopods. Based on the Order of the largest levels of determined contaminants in the Republic of Croatia from 2007, the highest permissible concentration of lead in shells is $1.50 \mathrm{mg} / \mathrm{kg}$ and cadmium $1 \mathrm{mg} / \mathrm{kg}$. On the other hand, the values of lead, cadmium and mercury in crabs must not exceed values greater than $0.50 \mathrm{mg} / \mathrm{kg}$ of fresh meat.

In seawater research at Ennore creek in southeast coast of India, much higher values of chromium, lead and cadmium were obtained than in our research [41]. Wang et al., 2012 [42] indicated that heavy metal pollution in the Jinzhou Bay was serious, and values of heavy metals in seawater were much higher than FAO and WHO recommendations. Values of heavy metals in coastal area of Tuaran in Malaysia were in the range of acceptance limit except for lead in seawater was considered slightly polluted in research of Tan et al., 2016 [43]. Analysis of sediment done by Vukadin et al., 1994 [44] showed that higher values of heavy metals in some areas (Split and Šibenik) could be attributed to anthropogenic effects. These results suggests that the southern part of the Adriatic Sea has much less pollution compared to other seas around the world.

\section{CONCLUSION / Zaključak}

Our investigation of electrolyte composition in coelomic fluid is important for understanding the biology of sea urchins, modified from the aspect of osmoregulation and physiological adaptations in changed conditions of the sea environment. This type of study is vital in anticipating the toxic impacts of contamination on living organisms.

This is the first study of heavy metal concentrations in coelomic fluid of sea urchin, Arbacia lixula in Hvar channel, therefore, further studies should be carried out in the future, analysing and comparing a wider area of Adriatic sea. The animal collection, maturity, health condition and feeding status could introduce additional variation in the common electrolites composition, so further investigations should be focused on these factors too. A comparison of obtained results with recent research for the Adriatic and the Mediterranean Sea shows that our values are within the range of values most commonly found in low polluted areas of the Adriatic sea. The ecosystem of the Hvar channel area is not seriously polluted with heavy metals based on analysis of coelomic fluids in echinoderms. Finally, the obtained data could act as reference information for this part of Adriatic sea.

\section{REFERENCES / Literatura}

[1] Diehl, W. J.: Osmoregulation in echinoderms. Comparative Biochemistry and Physiology Part A: Physiology 1986, Vol. 84, No 2, pp. 199-205, DOI: 10.1016/0300-9629(86)90605-5.

[2] Freire, A., Santos, A. I. \& V. Dennilton: Osmolality and ions of the perivisceral coelomic fluid of the intertidal sea urchin Echinometra lucunter (Echinodermata: Echinoidea) upon salinity and ionic challenges, Zoologia (Curitiba), 2011, Vol. 28 , No 4, pp. 479-487, (ISSN: 1984-4670), DOI: 10.1590/S1984-46702011000400009.

[3] Vidolin, D., Santos-Gouvea, I. A., \& C. A. Freir: Differences in ion regulation in the sea urchins Lytechinus variegatus and Arbacia lixula (Echinodermata: Echinoidea), Journal of the Marine Biological Association of the United Kingdom, 2007, Vol. 87, No 3, pp. 769-775, (ISSN 0025-3154), DOI: 10.1017/ S0025315407054124.

[4] Yildirim, Y., Gonulalan Z., Narin I. \& M. Soylak: Evaluation of trace metal levels of some fish species sold at retail in Kayseri, Turkey. Environmental Monitoring Assessment, 2009, Vol. 149, pp. 223-228. DOI: 10.1007/s10661-008-0196-7.

[5] Blackmore, G. \&W. X. Wang: Uptake and efflux of Cd and $\mathrm{Zn}$ by the green mussel $P$. viridis after metal pre-exposure, Environmental Science and Technology, 2002, Vol 36, pp. 989- 995, DOI: 10.1021/es0155534.

[6] Chapman, P. M \& E.R. Long: The use of bioassays as part of a comprehensive approach to marine pollution assessment, Marine Pollution Bulletin, 1983, Vol 14, No 3, pp. 81-84, DOI: 10.1016/0025-326X(83)90305-3.

[7] Nekvapil, F, Tomčić, S. \& S. C. Pinzaru: Comparative Raman Spectroscopy Study of the Coelomic Fluid of Grazing Sea Urchins and Their Native Seawater: Prospect for A Potential Indicator of Environmental Aggression, Air and Water Components of the Environment Conference, 2018, DOI: 10.24193/ AWC2018_04.

[8] Sala, E., Ribes, M., Hereu, B., Zabala, M., Alva, V., Coma, R. \& J. Garrabou:Temporal variability in abundance of the sea urchins Paracentrotus lividus and Arbacia lixula in the northwestern Mediterranean: comparison between a marine reserve and an unprotected area, Marine Ecology Progress Series, 1998, Vol. 168, pp. 135-145, DOI: 10.3354/meps168135.

[9] Kahn, S. \& N. Dayanthi: 2007. Sensitivity of juvenile freshwater crayfish Cherax destructor (Decapoda: Parastacidae) to trace metals. Ecotoxicology and Environment Safety, 2007, Vol. 68, No 3, pp. 463-469, (ISSN 0147-6513). https:// doi.org/10.1016/j.ecoenv.2006.08.003

[10] Gulec, A. K. \& O. Asku: Effects of handling on physiological profiles in turkish crayfish, Astacus Leptodactylus World Journal of Fish and Marine Sciences 4, 2012, Vol. 4, No 6, pp. 684-688, (ISSN 2078-4589), DOI: 10.5829/idosi. wjfms.2012.04.06.65103. 
[11] Kouba, A., Milos, B. \& P. Kozak: Bioaccumulation and effects of heavy metals in crayfish: A review. Water Water Air and Soil Pollution, 2010, Vol. 211, No 1, pp. 5-16, DOI: 10.1007/s11270-009-0273-8.

[12] Auernheimer, C. \& S. Chinchon: Calcareous skeletons of sea urchins as indicators of heavy metals pollution. Journal Environmental Geology, 1997, Vol. 29, No 1, pp. 78-83, DOI: $10.1007 / \mathrm{s} 002540050106$.

[13] Livingstone, B. T. \& F.H. Wilt: Injection of myo-inositol reverse the effects of lithium on sea urchin blastomeres. Development Growth Differentiation,1995, Vol. 37, No 5, pp. 539-543, DOI: 10.1046/j.1440-169X.1995.t01-4-00008.x.

[14] Kitazawa, C. \& S. Amemiya: Evagination of the amniotic cavity in larvae derived from lithium-treated embryos of a direct developing echinoid, Peronella japonica. Journal of Experimental Zoology, 1997, Vol. 79, No 3, pp. 309-312 DOI: 10.1002/(SICI)1097-010X(19971015)279:3<309::AID-JEZ12>3.0.CO;2-4.

[15] Böttger, S. A, Walker, C. W \& Unuma T: Care and Maintenance of Adult Echinoderms. Methods in Cell Biology, 2004, Vol. 74, pp. 17-38, DOI: 10.1016/ S0091-679X(04)74002-9

[16] Mann, K., Poustika, A.J. \& M. Mann: The sea urchin (Strongylocentrotus purpuratus) test and spine proteomes, Proteome Science, 2008, Vol. 6, No 22 DOI: 10.1186/1477-5956-6-22

[17] Leverone, J. R., Luer, C. A. \& J.M. Lawrence: The effect of cations on the specific activities of pyruvate kinase and glucose-6-phosphate dehydrogenase of Luidia clathrata (Say) (Echinodermata: Asteroidea), Comparative Biochemistry and Physiology, 1991, Vol. 99 (B), pp. 259-264. https://doi.org/10.1016/03050491(91)90038-f

[18] Motokawa, T.: Effects of ionic environment on viscosity of triton-extracted catch connective tissue of a sea cucumber body wall, Comparative Biochemistry and Physiology, 1994, Vol. 109 (B), pp. 613-622. https://doi.org/10.1016/03050491(94)90124-4

[19] Wilkie, I. C., Emson, R. H. \& C. M. Young: Variable tensility of the ligaments in the stalk of a sea-lily, Comparative Biochemistry and Physiology, 1994, Vol. 109(A), pp. 633-641. https://doi.org/10.1016/0300-9629(94)90203-8

[20] Trotter, J. A. \& K. Chino: Regulation of cell-dependent viscosity in the dermis of the sea cucumber Actinopyga agassizi, Comparative Biochemistry and Physiology, 1997, Vol. 118(A), pp. 805-811. https://doi.org/10.1016/s03009629(97)00055-8

[21] Hagen, N. T.: KCl induced paralysis facilitates detachment of hatchery reared juvenile green sea urchins, Strongylocentrotus droebachiensis, Aquaculture 2003, Vol. 216, No 1/4, pp. 155-164, (ISSN: 0044-8486), DOI: 10.1016/S00448486(02)00510-0.

[22] Brennand, H. S., Soars, N., Symon A. Dworjanyn, S. A., Andrew R. Davis, A. R. \& M. Byrn: Impact of Ocean Warming and Ocean Acidification on Larva Development and Calcification in the Sea Urchin Tripneustes gratilla, Ices Journal of Marine Science, 2010, Vol. 69, No 3, DOI: https://doi.org/10.1093/ icesjms/fsr123.

[23] Kobayashi, N.: Marine pollution bioassay by sea urchin eggs, attempt to enhance sensitivity. Publication of the Seto Marine Biological Laboratory, 1990 Vol. 34, No 4-6, pp. 225-237, DOI: 10.5134/176165.

[24] Kobayashi, N.: Bioassay data for marine pollution using Echinoderms. In Cheremisinoff K., (editor) Encyclopedia of Environmental Control Technology. Gulf Publications, Houston, 1995, pp. 16.

[25] Soualili, D., Dubois, P., Gosselin, P., Pernet P. \& M. Guillou:. Assessment of seawater pollution by heavy metals in the neighbourhood of Algiers: use of the sea urchin, Paracentrotus lividus, as a bioindicator. Journal of Marine Science, 2008, Vol. 65, No 2, pp. 132-139, DOl: https://doi.org/10.1093/icesjms/fsm183.

[26] Lavill, I., Vila, P., Milos, B. \& C. Bendicho:. Development of an ultrasound-assisted extraction method for biomonitoring of vanadium and nickel in the coastal environment under the influence of the Prestige fuel spill (north east Atlantic Ocean). Analytica Chimica Acta. 2006, Vol. 577, No 1, pp. 119-125, DOI: https:// doi.org/10.1016/j.aca.2006.06.021

[27] Orescanin, V., Lovrencic, I., Mikelic, L., Barisic, D., Matasin, Z., Lulic, S. \& D. Pezelj: Biomonitoring of heavy metals and arsenic on the east coast of the Middle Adriatic Sea using Mytilus galloprovincialis, Nuclear Instruments and Methods in Physics Research, 2006, Vol. 245, No 2, pp. 595-600, DOI: https://doi. org/10.1016/j.nimb.2005.11.050.
[28] Bonsignorea, M. Mantaa, D. S., Mirtob, S., Quincia, E. M, Apea, F, Montaltob, V., Gristinac, M., Trainaa, A. \& M. Sprovieria: Bioaccumulation of heavy metals in fish, crustaceans, molluscs and echinoderms from the Tuscany coast, Ecotoxicology and Environmental Safety, 2018, Vol. 162, pp. 554-562, DOI: 10.1016/j.ecoenv.2018.07.044.

[29] Nolan, C. V., Fowler, S. W. \& J. L. Teyssie: Cobalt speciation and bioavailability in marine Organisms. Marine Ecology Progress Series, 1992, Vol. 88, pp. 105-116, DOI: 10.3354/meps088105

[30] Nagpal, N. A.: Water Quality Guideline for Cobalt. Technical Report. British Columbia: Water Protection Section: Water, Air and Climate Change Branch; Ministry of Water, Land and Air Protection, 2004.

[31] Kim, J. H., Gibb, J. H. \& P. D. Howe: Concise International Chemical Assessment Document 69, Geneva: World Health Organization, 2006.

[32] Tellis, M. S., Lauler, M. M., Nadella, S., Bianchini A. \& A. M. Wood: Subletha Mechanisms of Pb and Zn Toxicity to the Purple Sea Urchin (Strongylocentrotus purpuratus) during Early Development, Aquatic Toxicology, 2014, Vol. 146, pp. 220-229, DOI: https://doi.org/10.1016/j.aquatox.2013.11.004.

[33] Gokoglu, N., Yerlikaya, P. \& M. Gokoglu: Trace elements in edible tissues of three shrimp species (Penaeus semisulcatus, Parapenaeus longirostris and Paleomon serratus), Journal of the Science Food Agriculture, 2008, Vol. 88, No 2, pp. 175-178, DOI: https://doi.org/10.1002/jsfa.3086.

[34] Offem, B. O. \& E. O. Ayotunde: Toxicity of lead to freshwater invertebrates (water fleas; Daphnia magna and Cyclops sp.) in fish ponds in a tropical floodplain. Water Air and Soil Pollution, 2008, Vol. 192, No 1-4, pp. 39-46, (ISSN: 1573-2932), DOI: 10.1007/s11270-008-9632-0.

[35] Vinodhini, R. \& M. Narayanan: Bioaccumulation of heavy metals in organs of fresh water fish Cyprinus carpio (Common carp), International Journal Environmental Science \& Technology, 2008, Vol. 5, No 2, pp. 179-182, (ISSN: 1735-2630), DOI: 10.1007/BF03326011.

[36] Gundogdo, A., Harmantepe, F.B., Karsli, Z. \& G. Dogan: Elimination of coppe in tissues and organs of rainbow trout (Oncorhynchus mykiss, Walbaum, 1792) following dietary exposure, Italian Journal of Animal Science, 2011, Vol. 10, No 1, pp. 1-6, DOI: 10.4081/ijas.2011.e1.

[37] Ciacci, C., Barmo, C., Fabbri, R., Canonico, B., Gallo, G. \& L. Canesi: Immunomodulation in Mytilus galloprovincialis by Non-Toxic Doses of Hexavalent Chromium, Fish Shellfish Immunology, 2011, Vol. 31, No 6, pp. 1026-1033, DOI: 10.1016/j.fsi.2011.09.002.

[38] Ciacci, C., Barmo, C., Gallo, G., Maisano M., Capello T., D'agata, A., Leonzio, C., Mauceri, A., Fasulo, S. \& L. Canesi: Effects of Sublethal, Environmentally Relevant Concentrations of Hexavalent Chromium in the Gills of Mytilus galloprovincialis, Aquatic Toxicology, 2012, Vol. 120-121, pp. 109-118, DOI: 10.1016/j.aquatox.2012.04.015.

[39] Mance, G.: Pollution Threat of Heavy Metals in Aquatic Environment, Elsevier Applied Sciences, New York, 1987, pp. 372.

[40] Kumara, C. S., Jaikumarb, M., Robin, R. S., Karthikeyan, P. \& C. S. Kumar: Heavy Metal Concentration of Sea Water and Marine Organisms in Ennore Creek, Southeast Coast of India, The Journal of Toxicology and Health, 2013, Vol. 103, pp. 192-201, ISBN: ISBN: 2294-7439.

[41] Wang, J., Liu, R. H., Yu, P., Tang, A.K., Xu, L. K. \& J. Y. Wang: Study on the Pollution Characteristics of Heavy Metals in Seawater of Jinzhou Bay, Procedia Environmental Sciences, 2012, Vol. 13, pp. 1507 - 1516, DOI: 10.1016/j. proenv.2012.01.143.

[42] Tan, W. H., Tair, R., Mohd Ali, S. A., Talibe, A., Sualin, F. \& C. Payus: Distribution of heavy metals in seawater and surface sediment in coastal area of Tuaran Sabah, 2016, Transactions on Science and Technology, Vol. 3 (1-2), pp. 114122, ISSN 2289-8786.

[43] Vukadin, I., Odžak, N. \& J. Radačrić: Heavy Metal Pollution in Sediment from the Eastern Adriatic Coast, Croatia, Chemistry and Ecology, 1994, Vol. 8, No 4 pp- 265-274, DOI: 10.1080/02757549408038553. 